\title{
NOVICE TEACHERS' BELIEFS ABOUT PROBLEM-BASED LEARNING APPROACH, AND TEACHING PRACTICES
}

\section{Olena Zhukova ${ }^{1}$}

\begin{abstract}
This article presents the results of the pilot study conducted with the aim to examine novice teachers' pedagogical beliefs and challenges regarding the implementation of a problem-based learning (PBL) approach in the EFL classroom. The relationship and discrepancies between novice teachers' pedagogical beliefs and actual classroom practices were also investigated. In total 25 novice teachers of English as a foreign language (EFL) with up to 3 years of teaching experience participated in the study.

The data for the present study were collected from face-to-face semi-structured interviews and classroom observations. In total, 25 novice EFL teachers working in Latvian basic and secondary schools agreed to participate in the survey.

The finding of the survey suggest that novice teachers' beliefs are not always reflected in their actual classroom practices for a number of external and internal constraints, such as students' expectations and perceptions, school administrators' demands and lack of commitment, context of teaching, lack of professional skills and methodological support, and examination pressure.

These findings of the present study might have implications for school administrators, EFL teacher educators, teacher training institutions and the institution that provide teacher professional development courses, as well as for education policy makers and for EFL teachers themselves.
\end{abstract}

UDC Classification: 37.01; DOI: http://dx.doi.org/10.12955/cbup.v5.1046

Keywords: novice teachers, efl, teacher's beliefs, problem-based learning, PBL

\section{Introduction}

The current study focuses on novice EFL teachers' beliefs about teaching and learning and about the PBL approach in particular, as well as the novice teachers' actual classroom practices. Teachers' beliefs about a problem-based learning approach to EFL teaching include three related components: pedagogical beliefs about teaching and learning, self-efficacy beliefs about the implementation of PBL in the classroom, and beliefs about the perceived value of this approach for student learning. A significant question is, how do teachers' beliefs about teaching and learning compare with their classroom practices? This question is of great importance because, as Mishra \& Mehta (2017:8) put it, "despite what the experts say and believe, the actual implementation of new approaches to teaching and learning in today's schools and classrooms will be determined by the beliefs and knowledge of the practitioners themselves." Although a wealth of literature points to the importance of investigating teachers' beliefs and practices (e.g. Richards et al. 2001, and Fives \& Gill 2014) in order to improve teacher preparation and teaching quality, empirical studies on novice teachers' beliefs about teaching procedures and practices, particularly in foreign language teaching, are limited in Latvia. There is also little research on innovative non-directive teaching methods and techniques to promote $21^{\text {st }}$ century skills in the EFL classroom, and particularly on the implementation of the PBL approach. Therefore, this study seeks to understand the novice EFL teachers' beliefs about teaching and learning in general and about the use of a PBL approach in EFL teaching in particular compares to what teaching methods, techniques, and approaches the novice teachers actually apply in their practice. Answering this question could help experts and practitioners to understand better what teachers think about teaching in contrast to what they actually do in their classrooms and why.

The article includes the following sections: literature review on novice teachers' beliefs and problembased learning approach in EFL teaching, a description of the data and methods used in the study, the results and discussion, and finally the conclusions made.

\section{Literature review}

Novice teachers' preparation, induction, professional development, classroom experiences and practices have received much attention especially in the last years. Recent studies demonstrate that the initial years of teaching determine novice teacher's future career in that it influence their values, attitudes, professional competence, behavior, and motivation. Some studies also prove that novice teachers are often less effective than their more experienced colleagues due to lack of prior teaching

\footnotetext{
${ }^{1}$ Daugavpils University, The Faculty of Education and Management, Vienības Str. 13, Daugavpils, LV-5401, Latvia, lerial2@inbox.lv
} 
experience, professional knowledge and skills (Melnick \& Meister 2008; Schwarzer \& Grinberg 2016). Yet it is unarguable that teachers' professionalism is the main factor to determine success and failure of education. Along with that, the nature, content, and objectives of education are undergoing dramatic changes recently due to the rapid advances and transformations of the world that we live in today (Misha \& Mehta 2017). Many experts in education are highly concerned about the fact that current traditional pedagogical practices, models, methods and approaches have proven to be generally ineffective due to their inability to prepare students for the changes and demands of the 21st century global and knowledge-based economy. It is also true that today's students are fundamentally different from students in the past; they have different learning goals and require different teaching approaches. Therefore, it is becoming obvious today that in order to be able to face the $21^{\text {st }}$ century challenges, $21^{\text {st }}$ century teachers are required to transform their educational practices, methods, approaches, and roles (Mishra \& Mehta 2017; Johnson 2013; Kern 2012). Similarly, education in Latvia is also experiencing an evolutionary transformation and paradigm shift in order to increase its effectiveness and relevance to the needs and requirements of the globalized knowledge-based society. According to the report of the Latvian national center for education, the priority and key objective of the state general education in Latvia is to enhance and facilitate the development of students' competencies, skills, and experiences that they need to succeed professionally, socially, and personally in today's increasingly globalized, pluralized, diverse, information and knowledge-based world.

\section{Teachers' beliefs}

There has been recently an increasing interest for the study of novice teachers' beliefs, attitudes, practices, and experiences (e.g. McAninch 2003; Schwarzer \& Grinberg 2016; Kersaint et al. 2007; Ingersoll et al. 2014). Teachers' beliefs, being one of the key constructs in teacher cognition, have frequently been discussed in scientific literature for more than 50 years (Fives \& Gill 2014). Many previous studies investigated teachers' beliefs about the teacher's and students' roles, pedagogical practices, instruction, and the ways a certain subject or skill should be taught (Khader 2012; Erkmen 2014; Larenas et al. 2015; Phipps \& Borg 2009). According to Kagan (1990), teaching beliefs are "highly personal ways in which a teacher understands classrooms, students, the nature of learning, the teachers' role in the classroom, and the goals of education" (p.423). Various studies have shown that teachers' pedagogical beliefs are important for understanding and improving teaching quality, teacher's education, and the effectiveness. Teachers' beliefs are considered to guide teachers' actions, instructional decisions, judgments, and behavior in the classroom. In addition, teachers' beliefs, attitudes and practices shape students' learning environment and influence their learning motivation and outcomes (Subramanian 2014; McCoaghan 2008; OECD 2009; Richards et al. 2001; Patch 2008). Pajares (1992) also adds that the investigation of the beliefs of pre-service and in-service teachers should be a focus of educational research since it provides valuable data "in ways that prevailing research agendas have not and cannot."

Two major opposed types of teachers' beliefs about teaching and learning philosophy are commonly compared and contrasted in contemporary research, namely, the direct transmission philosophy (also referred to as traditional views or traditional pedagogical practices) and constructivist philosophy or views about teaching and learning (sometimes also referred to as 21 st century teaching and learning or non-directive teaching). Direct transmission beliefs about teaching and learning implies that the factual knowledge is presented and conveyed by an active teacher to passive students; the teacher's role is to transmit the knowledge and information in a clear and structured way, to give student clear problems and provide correct solutions to the problems, to tell students what they should and should not learn, know, memorize, and use, as well as to control the discipline in the classroom. The relationship between teacher and students are typically power-distance or power-based; the learning process is viewed as teacher-centred (OECD 2009; Carroll 2014; Leonard 2002; McCoaghan 2008). Contrastingly, constructivist views imply that a teacher's role is to co-collaborate, guide, facilitate and coordinate the learning process, while the student's role is to actively participate in the process of acquiring and constructing knowledge. Students actively create their own knowledge based on their previous and new experience through investigations, questioning, discussing, and reasoning. Students are encouraged to take responsibility for their learning and to choose what they are really interested in, as well to research and develop multiple solutions to authentic problems on their own and in collaboration with others (OECD, 2009; Reevy \& Bursten 2015; McCoaghan 2008; Chow et al. 2015). 
A number of studies report about the inconsistency between the teachers' beliefs and their real classroom practices, which is often caused by various internal and external constraints (Erkmen, 2014; Phipps \& Borg 2009). The urgent problem here is that, as Park \& Ertmer (2007) put it, "encouraging teachers to develop new beliefs and stick with them is difficult." The authors add that even teachers with a strong set of pedagogical beliefs are likely not to put their beliefs and ideas into practice because of "the conditions of the teaching environment." Park \& Ertmer (2007) claim that even if a teacher has student-centred learning beliefs, he/she may "quickly adopt a teacher-centred approach when faced with an overloaded schedule, lack of administrative support, or other barriers in the classroom."

\section{Problem-based learning approach in EFL teaching}

Along with general education transformation, foreign language teaching has been undergoing dramatic shifts over the past few decades (Long \& Doughty 2011; Kern 2012; Fleming \& Stevens 2014). Problem-based learning (PBL) approach in foreign language teaching is one of the innovative constructivist teaching approaches in language classroom, which was first introduced in several American and Canadian medical universities in 1950s (Mathews-Aydinli 2007). Later PBL approach was adopted in teaching other subjects, including humanities; however, there is very limited research on the use of PBL in teaching language arts (Othman \& Shah 2013). Nevertheless, PBL is gradually gaining its popularity among EFL educators nowadays as it has proven to be an effective means for advancing students' content knowledge and higher-order thinking skills (Mathews-Aydinli 2007; Larsson 2001; Boothe 2011; Othman \& Shah 2013). PBL has been defined as "revolutionary and radical teaching approach" (Cheong 2008), "educational reform" (McCoaghan 2008), and a "constructivist method of instruction" (Pecore 2013; Subramanian 2014) that involves innovative teaching and learning methods and strategies, including teaching language in context, active and collaborative learning, trans-disciplinary learning, and inquiry-based learning. As Subramanian (2014) notes, the investigation of PBL implementation and effects in the school context is a relatively new topic in literature; however, recently, researchers have stressed the need for more PBL research that examines its effectiveness in the K-12 classrooms.

Barrows (1982) defines problem-based learning as a "learning method based on the principle of using problems as a starting point or stimulus for the acquisition and integration of new knowledge." PBL differs considerably from the traditional lecture-tutorial approach as it involves a shift from the traditional teacher-centeredness, content-orientedness, knowledge transmission, and student passive learning to the student-centeredness, process-orientedness, knowledge construction, and active learning (Cheong 2008; Tan 2003). Within the problem-based learning, a teacher presents students with a problem to solve in order to engage them in a process that involves objectives, problems, research experiences, solution development activities, discussions, and assessments (Pecore 2013). Being involved in PBL in the EFL classroom, students face a complex authentic problem or an uncertain problematic situation they have to solve by analysing authentic materials and communicating in the target language. The authenticity of the problems and of the materials involved, as well as the integration of current real-life events and situations have a highly positive impact on the students' motivation and stimulate development of higher-order thinking skills and intellectual processes such as problem solving, critical thinking, analysing, summarizing, hypothesizing, drawing conclusions, questioning, which leads to deeper understanding of the content and "enhanced retention and transferability of information and concepts" (Barell 2006; Williams \& Paltridge 2016; Othman \& Shah 2013; Larsson 2001). As Mathews-Aydinli (2007) puts it, "second language acquisition research and practice have long recognized the value of classroom interactions for promoting language acquisition, particularly when these interactions involve negotiation of meaning. When there is a focus on real-world issues and problems, the interactions that take place have been found to be more meaningful and authentic than interactions produced during activities such as assigned role plays or repetition of dialogues". Mathews-Aydinli (2007) also adds that PBL approach contributes to the development of skills for self-directed autonomous learning, allowing students to practically use the skills obtained in the classroom in their lives outside the classroom.

\section{Data and methodology}

The purpose of the research is to examine novice EFL teachers' beliefs and actual classroom practices regarding the use of a problem-based learning approach in EFL classroom. Specifically, the research 
seeks to answer the following questions: (1) What are novice teachers' teaching and learning beliefs and what are their actual classroom practices? (2) To what extent are novice EFL teachers comfortable with non-directive student-centred teaching practices and specifically with the PBL approach? (3) What challenges with their role do novice EFL teachers experience in regard to problem-based learning? To address the questions raised in the survey, qualitative data was obtained from face-toface semi-structured interviews with novice EFL teachers $(n=25)$, and classroom observations were taken. The data were collected between January 2016 and February 2017. Each teacher participating in the survey was observed twice during his/her EFL lesson. All the participants were interviewed orally and individually; each interview was held at school and lasted for 40-60 minutes. This study utilized qualitative data analysis. The interviews were recorded, transcribed, coded and further analyzed using a semantic content analysis method in order to identify categories and subcategories to describe the content (Corbetta, 2007:75). Initially, manual coding of each interview was conducted to identify words and phrases that correspond to the common themes for the purpose of this study. Then the data was analyzed for similarities and differences (research design adapted from Mahfoodh 2011:16 and Erkmen 2014:102-103).

\section{Participants}

25 novice EFL teachers, working in 19 Latvian comprehensive schools, agreed to take part in the survey. Table 1 below provides demographic information about the participants of the current survey. The participants were chosen on the basis of representativeness. All of them were teachers of English as a foreign language who have gone through at least four years of formal initial teacher training at a university level. Their full-time teaching experience varied from 4 months to 3 years. At the time of the survey they all worked in the urban public-school sector in either one of two of Latvia's largest cities Riga and Daugavpils.

Table 1: Demographic information about the participants of the study

\begin{tabular}{|c|c|c|c|c|c|}
\hline & $\mathbf{N}$ & $\%$ & & $\mathbf{N}$ & $\%$ \\
\hline Gender & \multicolumn{2}{|c|}{$(N=25)$} & Age & \multicolumn{2}{|c|}{$(N=25)$} \\
\hline Male & 4 & 16 & Under 22 & 7 & 28 \\
\hline Female & 21 & 84 & $23-27$ & 15 & 60 \\
\hline Education Level & & & 28 and older & 3 & 12 \\
\hline Bachelor's degree & 19 & 76 & Teaching experience & & \\
\hline Master's Degree & 6 & 24 & 4-6 months & 4 & 16 \\
\hline Place of work & & & 7-12 months & 5 & 20 \\
\hline Riga & 16 & 64 & 13-24 months & 9 & 36 \\
\hline Daugavpils & 9 & 36 & 25-36 months & 7 & 28 \\
\hline
\end{tabular}

\section{Results and Discussion}

1. Novice EFL teachers' beliefs about the nature of teaching and learning and their classroom practices

Barell (2006) claims that the frequency and effectiveness of the use of problem-based teaching and learning depends on various factors, including teachers' beliefs about the nature of teaching and learning. Therefore, the participants were asked first to comment briefly on their views about the nature of foreign language teaching and learning. The study revealed that the majority of the teachers surveyed tend to believe that students have to be actively involved into the learning process and take responsibility for their learning; $78 \%$ of the novice EFL teachers affirmed that students' achievements in language learning and their future success are largely dependent on their commitment, active involvement and participation in the learning process, as well as on teacher's professionalism. When asked about student motivation, more than a half of the novice teachers pointed to the importance and necessity to create such learning environment where their students feel secure, supported, valued, and respected; according to the teachers, their role is not to force students to learn, but to help them discover their true interests and strengths, boost their curiosity and willingness to learn and create. Additionally, of the 25 novice teachers who took part in the survey, over $80 \%$ replied that they find it highly important to meet the diverse learning needs and expectations of their students, although this task is viewed by the teachers as one of the most challenging ones. 
Nearly all of the participants declared that they have either mixed beliefs (traditional-constructivist) or constructivist beliefs about the nature of teaching and learning. Only 2 of the 25 teachers considered traditional pedagogical practices to be the most effective for students in terms of foreign language acquisition. However, the lesson observational data demonstrate that novice EFL teachers' beliefs are not always reflected in their actual classroom practices and that there are differences between the surveyed teachers' beliefs on the one hand, and their practices, on the other. This goes in line with OECD (2009), Larenas et al. (2013), Rajab et al. (2015), and a number of other scientists' findings concerning the relationship and discrepancies between teachers' beliefs about teaching and learning and their actual classroom practices.

Only less than a half of the teachers observed in this survey demonstrated the features of constructivist pedagogical practices, namely, student-centeredness, the use of problem-based learning activities and procedures, such as case studies, inquiry-based learning, etc. The observational data shows that most novice teachers demonstrate the features of more traditional lecture-based way of teaching and instruction, such as summarizing former lessons, homework review, checking the exercise book, presenting new material (facts, grammar rules, etc.), assigning activities, checking the solutions, and asking comprehension questions in every lesson, rather than those of the constructivist teaching. Specifically, the novice teachers, by and large, act as centre of attention and provider of information in their classrooms. They typically attempt to control everything that the students do during the lesson. The interviews data also show that a lot of novice teachers report being afraid of losing control in the classroom and struggling with discipline and behavior issues. This might be caused by the novice teachers' lack of prior teaching experience, lack of self-confidence, and practical skills to cope with challenging situations in the classroom, as well as with their inner need to prove themselves. These findings are consistent with earlier findings of Frederiksen et al. (2011), Wang \& Schwille (2008), Melnick \& Meister (2008); the researchers claim that novice teachers, especially in their first year of teaching, experience considerable challenges and concerns regarding classroom management, discipline, control over students, time management, etc. mostly due to the lack of confidence, as well as lack of practical experience, skills and knowledge.

Most novice teachers in this survey were likely to provide restricted information and instruct students what to do and what not to do with the information, how to use it, what to memorize and what not to memorize, rather than letting the students independently use information they need to construct their knowledge and understanding in a self-directed and not teacher-directed way. Also, the lesson observations revealed that more than a half of the teachers surveyed tend to use teachers-centred and direct teaching techniques more often. These teachers focus more on providing grammar rules, presenting clearly defined tasks and demonstrating correct solutions. It might be associated with the teachers' desire to keep the learning process under control ensuring that the learning process is well structured and adherent to the requirements of the curriculum. It might be also because some novice teachers are inclined to largely perceive their students as unmotivated and passive learners therefore the teachers are likely to avoid student-centred and non-direct teaching which gives students more autonomy. Students typically have little freedom to choose the learning tools, information sources and content. Only a quarter of the novice teachers in the study started and finished their lessons by asking for students' feedback. As to the academic environment of the classrooms being observed in the current study, the novice teachers tend to focus students' attention mostly on the memorization of different usually unconnected facts and rules. Several teachers, however, tend to focus more on developing students' language and communicative skills in different contexts taking into account their individual interests.

2. Novice EFL teachers' beliefs and actual classroom practices in regard to PBL in language teaching

Surprisingly, for $44 \%$ of the novice teachers participating in the survey it was quite challenging to provide any sufficient definition to the problem-based teaching and learning approach, therefore they could not answer the question whether they implemented this approach in their teaching practice. However, after being provided a brief explanation of the PBL, the participants were able to comment on their experiences with PBL. Only 7 of the 25 participants (28\%) indicated that they try to regularly use this approach in their practice; they also pointed that they would like to apply it more often provided that they have enough time and relevant resources. 8 of the participants (32\%) reported that they implement this kind of teaching approach occasionally, and 10 participants (40\%) indicated that 
they normally use the PBL approach "very rarely" or "never" in their day-to-day practice. Interestingly, that the majority of those surveyed (72\%) indicated that they acknowledge the importance of this approach in developing students' core language competences, information literacy, communicative and other higher-order thinking skills. The novice teachers also generally agreed that the PBL approach, in contrast to more traditional lecture-based and teacher-centred pedagogical practices, has great potential to actively engage students into the learning process and to motivate them to learn. When asked about their beliefs regarding the advantages and effects of PBL for language teaching, the novice teacher commonly concurred that PBL provides students with the opportunity to learn foreign language in context and unconsciously, by fulfilling many other actions in many varied contexts such as searching for information, reading the information, questioning, summarizing facts, discussing results with their peers and presenting them. Furthermore, some novice teachers reported having noticed that "difficult" students are likely to become more motivated if they are provided opportunity to take responsibility of their own learning and make their own decision on what and how to learn. However, the teachers also noted that in the context of their schools non-direct teaching activities such as PBL or project-based learning are very difficult to implement because of various reasons such as the need to strictly control the discipline and follow the curriculum.

\section{Challenges with PBL}

More than a half of the participating in the survey admitted that they had tried using problem-based activities in their EFL classrooms, but they seemed to be of little effectiveness due to various reasons. Most often the teachers mentioned that (1) it is often difficult to control the students and maintain the discipline in the classroom (2) such activities required too much time for instruction and explanation of tasks and did not give the students sufficient opportunity to practice; (3) such activities might be inappropriate for mixed ability classes and for weak students or for students with lower levels of language skills; (4) it is often difficult to encourage students to use the target language rather than their native language in group discussions. These findings go in line with McCoaghan's (2008) earlier findings that indicate that teachers' professional background influences the success and failures with problem-based learning facilitation.

When asked about the major challenges and concerns with the non-direct teaching and the PBL approach in language teaching, the majority of the teachers (80\%) especially emphasized the gap between theory and practice. These teachers share the opinion that theoretically today's pedagogical practices have to be transformed to meet the demands of the $21^{\text {st }}$ century; they also largely agreed that such innovative constructivist pedagogical practices as student-centeredness, mastery-orientedness (rather than performance-orientedness), knowledge construction, student self-directed active learning, as well as the integration of technology in teaching and learning should be predominant; however, practically there are many barriers that considerably hinder constructivist teaching in schools. Classroom management and discipline problems, lack of school administrators' commitment and support, lack of professional skills and prior experiences, lack of time, relevant teaching materials, pressure from the school administration and syllabus requirement, as well as poor classroom technical equipment were mentioned the most by the participants as the main challenges in terms of the implementation of PBL in foreign language classroom.

At least $50 \%$ of those interviewed indicated that they could not apply some of their pedagogical ideas and beliefs about teaching and learning in their classroom practice for a number of reasons including the contextual constraints and discipline problems in their classes. One of the most commonly mentioned constraints was "students' expectations." Some novice teachers claim that their students tend to prefer traditional instructions and activities. Interestingly, teachers commonly refer to students' unwillingness to accept new teaching methods and techniques, rather than relate their inability to use innovative teaching due to their own lack of appropriate teaching skills and style. Another considerable challenge with PBL is that novice teachers do not feel themselves comfortable with this approach. According to some answers, they feel that they need too much time and effort to prepare for PBL lessons, and they are often afraid of losing control over their students especially in more "difficult" classes. Indeed, previous studies indicate that PBL can be rather controversial and even criticized by teachers, especially by those who successfully implements more traditional pedagogical practices. For example, Larsson (2001) argues that not all teachers feel comfortable with PBL and even those who favor PBL "are sometimes reluctant to implement it because of the tremendous 
amount of work involved in fundamentally restructuring a course." Furthermore, there are also students who are likely to prefer and be more effective learners in traditional rather than in PBL classroom. This assumption is supported by several earlier studies that indicate that while some students benefit from collaborative learning, active discussions and debates, other might have better learning outcomes only when provided with detailed instructions and well-defined assignments (Larsson 2001).

Another considerable concern for the novice teachers in terms of PBL is the pressure of the curriculum and the requirement to prepare students for standardized final exams. This is consistent with the findings reported in literature, for example, by Subramanian (2014), who claims that "pressure from the school district to increase students test scores in standardized tests, changes in the current curriculum, and low expectations in students' ability and performance discouraged and dissuaded teachers from implementing any innovative reform-based instructional practices like PBL in the classroom".

A number of teachers also reported about the lack of practical skills and prior experience required to search for relevant materials, as well as to design, plan, and successfully implement the PBL activities in the EFL classroom so that the desired learning outcomes are well achieved. They also added that in theory they are very well informed about the need and importance of innovative pedagogical practices, approaches and techniques; however, in practice and in particular school context it often seems impossible, therefore they have to "obey the rules" and do what they are expected to do but not what they believe should be done in the classroom. These findings are consistent with McCaughan (2008) who indicates that "the transition from traditional teaching to facilitating with a constructivist-like method as a bumpy, sometimes unsuccessful road. When constructivist beliefs are not well enough conceptualized during teacher training, they are subject to erosion during teaching. Although preservice teachers applied constructivist principles during their teacher education coursework, these principles were abandoned in the first full time teaching job". Also, the majority (78\%) complained about the material shortage and lack of preparation time to design and adapt authentic materials to use them in a problem-based classroom so that they meet various students' interests and learning needs on the one hand, and curriculum goals on the other hand. A large number of participants admitted that "preparing their student for the final English exam which is highly content-oriented" is the major barrier to the implementation of innovative teaching practices such as PBL. School administrators' and policy-makers' expectations from teachers was also quite frequently mentioned constrain in this survey. This is probably due to the fact that in Latvia, teacher's performance is evaluated largely according to the final exam grades and academic achievements of their students.

Finally, the participants reported that one of the main concerns with the problem-based teaching is that it is difficult to determine the place of the PBL approach and activities in the English language curriculum.

\section{Conclusion}

To summarize, the study revealed that most teachers surveyed hold constructivist or mixed (traditional-constructivist) beliefs about teaching and learning. However, the observational data illustrated that most novice teachers in this study largely use traditional lecture-based and teachercantered pedagogical practices.

Based on the results, it is clear that on the one hand, almost all novice teachers are aware of the importance to transform today's education and to use innovative student-centred pedagogical practices; however, at a closer look, it becomes obvious that not all novice teachers are actually prepared or ready to do so due because of a number of factors. Respondents admitted that they often have to choose more traditional forms of classroom practices and instruction which was contrary to their actual beliefs about the nature of teaching and learning. The transition from traditional direct teaching to a non-direct constructivist teaching philosophy might be a considerable challenge for them since most teachers tend to adopt the pedagogical practices that they observed in their early years while being learners themselves and also which they have applied because the traditional school system makes teachers believe that they have to work this way. 
Furthermore, the present study revealed that novice EFL teachers require more specific professional training on the use of innovative student-centred teaching methods, techniques and approaches in EFL classrooms.

Although this study involves only 25 participants, and the results cannot be generalized, they might be useful for teacher educators, teacher education and professional development institutions, and school administrators as the study uncovers and provides insight into the realities of novice EFL teachers' beliefs and classroom practices.

\section{References:}

Barell, J.F. (2006) Problem-Based Learning: An Inquiry Approach. California: Corwin Press

Boothe, D., Vaughn, R., Hill, J., Hill, H. (2011) Innovative English Language Acquisition Through Problem-based Learning. Conference materials. International Conference - The future of education. Florence, Italy 16 - 17 June, 2011

Butler, S. M., (1998) The Process of Problem-Based Learning: A Literature Review. Journal of Health Occupations Education: Vol. 13: No. 1, Article 9.

Chow, J.Y., Davids, K., Button, C., Renshaw, I. (2015) Nonlinear Pedagogy in Skill Acquisition: An Introduction. Routledge

Cheong, F. (2008) Using a Problem-Based Learning Approach to Teach an Intelligent Systems Course. Journal of Information Technology Education. Volume 7, 2008

Erkmen, B. (2014). Novice EFL teachers' beliefs about teaching and learning and their classroom practices. Hacettepe University Journal of Education, 29 (1), pp.99-113.

Frederiksen L.L., Lund J.H., Beck M. (2016) Different Understandings of the Relationship Between Teacher Education and Professional Practice. Journal of the European Teacher Education Network. 2016, Vol. 11, 112-120

Farrell, T. S.C. (2008). Learning to teach language in the first year: a Singapore case study. In T. S. C. Farrell, (Ed.), Novice language teachers: Insights and perspectives for the first year (pp.43-56). London: Equinox Publishing Ltd.

Fleming, M., Stevens, D. (2014) English Teaching in the Secondary School. 2nd ed.: Linking Theory and Practice. Routledge Fives, H., Gill, M.G. (2014) International Handbook of Research on Teachers' Beliefs. Abingdon: Routledge

Ingersoll, R., Merrill, L., \& May, H. (2014). What are the effects of teacher education and preparation on beginning teacher attrition? Research Report (\#RR-82). Philadelphia: Consortium for Policy Research in Education, University of Pennsylvania.

Johnson, A. (2013) Effective Methods for 21ST Century Learning: A Teacher Action Research Project. Meridian: A K-16 School Computer Technologies Journal. Vol 16, No 2, 2013

Khader, F.R. (2012) Teachers' Pedagogical Beliefs and Actual Classroom Practices in Social Studies Instruction. American International Journal of Contemporary Research Vol. 2 No. 1; January 2012

Kern, R. (2012) Teaching language and culture in a global age: New goals for teacher education. AAUSC 2011 Volume: Educating the Future Foreign Language Professoriate for the 21st Century. Ed. Allen,H.W., Maxim, H.H. Cengage Learning Kagan, D.M. (1990) Ways of evaluating teacher cognition: Inferences concerning the goldilocks principle. Review of Educational Research, 60(3), 419-469

Kemp, S. (2005) Constructivism and problem-based learning. Learning Academy. Retrieved March, 21, 2017, from http://www.tp.edu.sg/staticfiles/tp/files/centres/pbl/pbl_sandra_joy_kemp.pdf

Larenas, C.D., Hernandez, P.A., Navarrete, M.O. (2015) A Case Study on EFL Teachers' Beliefs About the Teaching and Learning of English in Public Education. Porta Linguarum №23, enero 2015, pp. 171-186

Law, N., Yuen, A., Fox, R. (2011) Educational Innovations Beyond Technology: Nurturing Leadership and Establishing Learning Organizations. Springer Science \& Business Media

Melnick, S, and Meister D.G. (2008). "A Comparison of Beginning and Experienced Teachers' Concerns.” Educational Research Quarterly 31, no 3: 39-56

Mahfoodh O.H.A. (2011) A Qualitative Case Study of EFL Students' Affective Reactions to and Perceptions of Their Teachers' Written Feedback. English Language Teaching. Vol. 4, No. 3; September 2011

Mathews-Aydinli, J. (2007) Problem-Based Learning and Adult English Language Learners. Center for Adult English Language Acquisition. Washington: Center for Applied Linguistics. April 2007

McAninch, A.R. (2003) Teacher Beliefs and Classroom Performance: The Impact of Teacher Education. IAP

Mitchell R., Miles F. (2004) Second language learning theories (2nd ed.). London: Edward Arnold

Mishra, P. \& Mehta, R. (2017) What We Educators Get Wrong About 21st-Century Learning: Results of a Survey, Journal of Digital Learning in Teacher Education, 33:1, 6-19

McCoaghan, K. (2008) Problem-based learning tutors' beliefs and challenges. Burnaby: Simon Fraser University Library.

Othman, N., Shah, M.I.A. (2013) Problem-Based Learning in the English Language Classroom. English Language Teaching; Vol. 6, No. 3; 2013

Park, S.H., Ertmer, P.A. (2007) Impact of Problem-Based Learning (PBL) on Teachers' Beliefs Regarding Technology Use. Journal of Research on Technology in Education. JRTE, 40(2), 247-267 
Patch, M. R. (2008) Measuring Sustained Effects of a Diversity Course on Classroom Teacher Beliefs: A Retrospective Pretest Study. ProQuest

Pajares M.F. (1992) Teachers' Beliefs and Educational Research: Cleaning Up a Messy Construct. Review of Educational Research Fall 1992, Vol. 62, No. 3, pp. 307-332

Pecore, J. L. (2013). Beyond Beliefs: Teachers Adapting Problem-based Learning to Preexisting Systems of Practice. Interdisciplinary Journal of Problem-Based Learning , 7(2).

Phipps, S., \& Borg, S. (2009). Exploring tensions between teachers' grammar teaching beliefs and practices. System, 37(3), 380-390.

Richards, J.C., Gallo, P.B., Renandya, W. A. (2001) Exploring Teachers' Beliefs and the Processes of Change. SEAMEO Regional Language Centre, Singapore Retrieved March, 10, 2017, from http://www.chan6es.com/uploads/5/0/4/8/5048463/exploring-teacher-change.pdf

Subramanian, U. (2014) Teacher Beliefs and Practices in Designing and Implementing Problem Based Learning in the Secondary Mathematics Classroom: A Case Study. Dissertation, Georgia State University

Schwarzer, D., Grinberg, J. (2016) Successful Teaching: What Every Novice Teacher Needs to Know. Rowman \& Littlefield Tan, O.S. (2003) Problem-based Learning Innovation: Using problems to power learning in the 21 st century. Boston: Cengage Learning

Teaching Practices, Teachers' Beliefs and Attitudes. (2009) Chapter 4. Creating Effective Teaching and Learning Environments: First Results from TALIS - ISBN 978-92-64-05605-3. OECD 2009. pp. 83-135 